\title{
Lansky Performance Status 80
}

National Cancer Institute

\section{Source}

National Cancer Institute. Lansky Performance Status 80. NCI Thesaurus. Code C69424.

Active, but tires more quickly. 